DOI: 10.20472/IAC.2019.052.041

DANIEL FRANCOIS MEYER

TRADE Research Unit, NWU, South Africa

\title{
AN ASSESSMENT OF THE IMPORTANCE OF THE AGRICULTURAL SECTOR ON ECONOMIC GROWTH AND DEVELOPMENT IN SOUTH AFRICA
}

\begin{abstract}
:
In developing countries, the agricultural sector plays a much more important role in economic growth and development if compared the economies of developed countries which have more diversified economies. In South Africa, the agricultural sector's contribution to the economy in terms of GDP, employment and exports has been diminishing over the last 20 years. Policy uncertainty, productivity and other factors are having a negative impact on the sustainable growth of the agricultural sector. The sector has the potential to assist the struggling economy towards higher growth rates and to provide employment opportunities to more people, especially low skilled workers. This research paper has the objective to analyse the importance of the agricultural sector by applying an econometric model. An Auto Regressive Dynamic (ARDL) econometric model was employed to determine the nature of the relationship between economic growth and independent variables from the agricultural sector including net exports, employment, value added contribution and the gross operating surplus from 1996 to 2018. The findings indicated that both a short-run and long-run relationships exist between the variables included in the study. The study presents new insights that could possibly aid in developing the agricultural sector in South Africa and thus enabling it to compete on a global scale and contribute significantly to the local economy.
\end{abstract}

\section{Keywords:}

Agriculture, economic growth, employment, exports, South Africa

JEL Classification: C10, 013 


\section{INTRODUCTION AND BACKGROUND}

It is in the agricultural sector where the battle for economic development is won or lost (Sertoglu, Ugural \& Bekun, 2017). Agriculture is more important than what many governments and researchers may consider, and the sector is in many cases neglected (Marsh \& Pannell, 2000). Agriculture is one of the critical economic base sectors as a primary economic sector (Stats SA, 2018a) and is of critical importance in the creation of jobs, growth in exports and a positive balance of payments, growth in GDP, the creation of forward and backward linkages, and finally ensuring food security in a specific region (White, 2012). The South African Revenue Services (SARS) (2018) recorded that, overall, South Africa's agricultural exports, although fluctuating, have been on the rise. It is estimated that the aggregate value of agricultural exports increased by 17.4 percent, from R83 022 million in 2015/16 to R97 429 million in 2016/17 (DAFF, 2017). Agriculture was the largest contributor with an outstanding growth of $37.5 \%$ in the fourth quarter of 2017 (Manaka, 2018).

Although agricultural growth and economic growth increased post-1994 to 2017, the sector's contribution towards GDP has decreased from 3.9 percent to approximately 2.0 percent (IDC, 2018). However, agriculture is still a prominent economic sector in South Africa's economy, and is a major source of employment for labourers in rural locations and a stimulus for foreign inflows (Lewis, 2002). In spite the small share of GDP it holds, the sector performs the crucial role of acting as a backward and forward link to other sectors (DAFF, 2018). Considering that a large majority of South Afirca is poverty-stricken, the growth of agricultural production and the sector as a whole is seen as a crucial instrument for job creation and more importantly, an effective strategy for poverty reduction (World Bank, 2018; Pfunzo, 2017). South Africa has a population total of approximately 56.5 million people, of whom more than half are living under conditions of poverty (Stats SA, 2017b). In addition, this is coupled with high levels of unemployment at 27.5 percent in quarter 3, 2018 (Stats SA, 2018b). Job creation is regarded as a major economic objective for the South African government (Meyer, 2014). Addressing the inherent limitations in order to resolve the issue of employment is of paramount importance to the government. Amidst the high levels of unemployment, South Africa has been confronted with declining exports, alongside an ever-fluctuating exchange rate (World Bank, 2018). Since a significant number of the population is either poverty-stricken or unemployed, this reveals that a large majority of the country is dependent on the social security system (Malakwane, 2012).

Realising that the agricultural sector is one of the major drivers in the economy of South Africa, making the largest contribution to informal employment and absorbing low-skilled labourers, massive investments ought to be injected into the sector (The Presidency, 2017). South Africa produces a diversified range of agricultural products; however, a small percentage of overall agricultural production is exported. The sector is struggling to be competitive due to the disparity between the educational attainment of the labour force, participation and absorption rates having a tendency to lead to weak labour market results for those in possession of very low levels of education, as well as the inability of the South African export market to compete internationally, due to a lack of skills and knowledge. In addition to this, South Africa has a vulnerability to international price fluctuations and an imbalance in the agricultural products produced. The agriculture sector in SA is under pressure with ongoing climate change impacts as well as government policy of expropriation without compensation. The objective of this paper is to analyse the status quo of the sector as well as the impact of agricultural activities on the economy in the country. 


\section{REVIEW OF LITERATURE}

Agricultural development is a complex process that enhances progressive transformations within urban and rural settlements (Udemezue \& Osegbue, 2018). Furthermore, it has been well documented in the literature that agricultural development purposes to convalesce the physical and social well-being of the populace; as such, it is synonymous with rural development, since the two terms are distinguishable while also interlinked (Nwachukwu \& Ezeh, 2007). Agricultural and rural developments coexist, entailing that without agriculture productivity development, farm settlements are also less likely to develop since rural inhabitants rely on agriculture as means for revenue generation (Dethier \& Effenberger, 2012). As such, an advanced agriculture sector produces a ripple effect of an economic and social nature (Dercon \& Gollin, 2014).

According to Johnston and Mellor (1961), the agricultural sector is important and growth in the sector can be realised by an extension of demand for agricultural goods; promotion of exports; and increases in capital formation for agricultural advancement. Romer's (1994) endogenous growth theory asserts that new knowledge or technology stimulates economic growth, and the agriculture sector could prove quite significant in this regard (Cortright, 2001). The World Bank (2007) emphasises the significance of agriculture at the primary stage of development; more rigid policy solutions, particularly in poor regions (e.g. sub-Saharan Africa), may propel the sector's growth potential. Equally, advancements in agricultural output are pivotal to economic development and growth (Gollin et al. 2002). Arguably, growth in the agriculture sector is a major driver for economic growth. In a similar fashion, conventional growth models, with unequivocal agricultural sectors, present sound forecasts regarding the capacity of agricultural output in net economic growth (Echevarria, 1997; Gollin et al., 2002). Overall, the recommended approach for agriculture development is the growth of agricultural output established on labour-intensive, capital-saving practices that fully depend on technological novelties (Delgado \& Mellor, 1984). This is consistent with the Solow growth model (1956), which highlights the implementation of a constant amalgamation of capital and labour, inclusive of technological advancements or innovation. This is supported by the export-led growth hypothesis (based on the foundations of the Keynesian theory), which argued that the expansion of exports can accelerate economic growth and development in the form of technological spillovers and other positive externalities (Thaker et al., 2013; Mohr et al., 2015). It maintains the premise that inclusive growth is more inclined to occur under conditions of increased employment, capital and enlarged export volumes (Medina-Smith, 2001; Marin, 1992).

This section of the study provides an analysis of empirical studies on the role and impact of the agricultural sector on the economy. Awokuse and Xie (2015) investigated the research question of how important the agricultural sector is for economic growth in nine developing countries. The findings show that the sector can act as an engine of growth that supports the agriculture-led growth hypothesis, but each country or region is different, with different levels of impacts. In addition, the results for some countries indicate that a strong and growing economy is a prerequisite for agricultural development. Diao, Hazell and Thurlow (2010) analysed the role of agriculture in African development and found limited evidence that indicates that African countries can have economic transformation and development by not implementing a well-developed agricultural sector with structural changes to successfully launch their economic transformations. Byerlee, De Janvry and Sadoulet (2009) investigated the role of agriculture for development within a changing environment. The agricultural sector 
has always been seen as an important economic sector for economic development, but globalisation, changing integrated value chains, rapid technological and institutional innovations, and environmental constraints have changed the context for agriculture's role. Possible recommendations include shifting to policy biases more towards rural and agricultural support, strengthening governance for agriculture, and tailoring priorities to country conditions. Foster and Rosenzweig (2004) state the importance of the development of the agricultural sector for development and wealth as well as the diversification of the economy. Land for agriculture is fixed and therefore the only way to increase output in agriculture is via improved productivity. Irz, Lin, Thirtle and Wiggins (2001) explained the importance of the agricultural sector for economic growth. These factors include employment creation, assisting in the growth of the rural regions, and prevention of food insecurity and cheaper food prices. Izuchukwu (2011) analysed the role of agriculture on economic development in Nigeria from 1986 to 2007. The sector is an important sector in the economy and is driving growth in the economy. Agriculture in Nigeria is limited due to low yields and productivity, and limited government support. The sector could be improved via improved research, allocation of funding and finance, improved productivity, and export focus.

In general, an increase in exports, including agricultural products, usually contributes to economic growth, especialy the export of value-added products (Hesse, 2009). In a study in Nigeria by Olajide et al. (2012), the results indicate positive cause and effect relations between GDP and agricultural output. Along these lines, Bakari and Mabrouki (2017) asserted that, based on empirical results, agricultural exports possess a strong positive correlation with economic growth in comparison to other sectors. This substantiates the theory that agricultural exports have a positive impact on the economic growth of several South Eastern Europe countries, thereby making it a catalyst for economic growth. In a study in Pakistan conducted by Mahmood and Munir (2017), it was revealed that agricultural exports have a positive yet insignificant correlation with economic growth. This is attributed to the sector's inability to participate in the global market because of competition, inferior quality products and expensively priced goods; as a result, agricultural goods do not have a significant impact on economic growth (Mahmood \& Munir, 2017). In stark contrast to the outcomes above, Mehrar and Baghbanpour (2016) concluded, based on estimated results, that agricultural exports have zero impact on the economic growth of a developing nation. Instead, total fixed capital formation in a developing economy is imperative to growth and development. Faridi (2012) analysed the level of contribution of exports in agricultural to economic growth in Pakistan for the period 1972 to 2008. The findings from this study are interesting and in conflict with mainstream results. Findings indicate that agricultural exports have a significantly negative effect on economic growth with an elasticity coeficient of 0.58 . Further results show that a bidirectional causality exists between agricultural exports and real GDP.

De Janvry and Sadoulet (2009) state that the agricultural sector is important for poverty alleviation and the sector has the potential to create linkages to the rest of the sectors in the economy. Cervantes-Godoy and Dewbre (2010) analysed the role and importance of agriculture on economic growth and poverty reduction by analysing 25 developing countries that achieved poverty alleviation access. Findings indicated that, of all the economic sectors, the agricultural sector through the incomes generated through this sector played a significant role. Pauw and Thurlow (2011) analysed the impact of the agriculture sector on economic growth, poverty and nutrition in Tanzania. Interesting results from the study indicate that economic growth did not lead to lower levels of poverty in the country. The structure of the agricultural sector did not allow the sector to positively impact on growth or poverty levels. The 
sector was dominated by large commercial farmers who did not assist the poor population as they were located in a few regions with a focus on crop farming. The study found that food production will strengthen the growth-poverty relationship and enhance households' caloric availability, while also contributing significantly to growth itself.

Tiffin and Irz (2006) analysed the direction of causality between agricultural value added per worker and gross domestic product (GDP) per capita, using the Granger causality tests. It was found that value-added activities in the sector clearly cause GDP changes. Thirtle, Lin and Piesse (2003) analysed the impact of improvements in agricultural productivity on poverty alleviation in developing countries. As much as $90 \%$ of the world's poor live in rural regions of Asia and sub-Saharan Africa. The study found that improvements in technology in the agricultural sector lead to effective increases in productivity. This gives effect to higher outputs and leads to reductions in poverty. Raza, Ali and Mehboob (2012) analysed the impact of agriculture on economic growth of Pakistan from 1980 to 2010, and results indicate that agriculture with all its sub-sectors contribute significantly to economic growth. In Pakistan, sub-sectors such as crops and livestock contributed more than $90 \%$ to the aggregate agriculture sector. Some of the stumbling blocks impacting negatively on the growth of the sector include low investment intensity in this sector, insufficient facilities, as well as an untrained and unskillful labour force engaged with it. Turan Katircioglu (2006) investigated the causal relationship between the agricultural sector and economic growth in North Cyprus from 1975 to 2002. Results indicate that agricultural output growth and economic growth are cointegrated with a long-run relationship with a bidirectional causation among the variables. Eddine Chebbi (2010) analysed the relationship between agriculture and economic growth in Tunisia. Overall, findings indicated that all economic sectors have long-run relationships and the agricultural sector does have linkages with the other economic sectors. However, the existence of a well-developed financial and credit market has a negative imapct on agricultural output in Tunisia.

Gollin (2010) investigated the relationship between productivity in agricultural and economic growth in poor developing countries, where the majority of people are poor and live in rural regions and survive via the agricultural sector. This sector dominates the economy in poor countries and contributes as much as $25 \%$ of GVA output to the total economy. Impact and changes in the sector, such as changes in the prodcutivity, have major effects on the total economy. In poor countries, however, productivity is low in the sector if compared to other sectors in the economy. The study found significant correlations between agricultural productivity increases and economic growth, but limited evidence for a causality. Po-Chi, Ming-Miin, Chang and Shih-Hsun (2008) analysed the total factor productivity growth in China's agricultural sector from 1990 to 2003. The results indicate that technical progress is the main source for productivity growth in the agricultural sector and that productivity levels are different for all regions, and conversion is not happening. The determinants for technical progress include tax incentives, research and development intitiatives, investment in infrastructure, mechanisation, education and disaster mitigations.

In summary, the agriculture sector is complex and is an integral part of rural development. From the literature, there is consensus that agriculture is an important sector in especially poor developing countries allowing for labour intensive growth as well as exports and surplus on the balance of payments. Although the sector is characterised by lower levels of innovation and technology, advancement in innovation is important for improved productivity. 


\section{RESEARCH METHODOLOGY}

The methodology of this research study follows a quantitative research approach with the use of secondary data, alongside a functionalist paradigm. Within the primary objective of the study, which is to determine the importance of the agricultural sector for economic growth in South Africa, a quantitative research methodology was selected. In a time-series analysis, the relationships between economic variables in the agricultural sector such as exports, income, productivity, employment and value added production are related to economic growth in South Africa. Secondary data used in the study were collected from Global Insight Regional Explorer dataset (2019) and Quantec Easy Dataset (2019) from 1996 to 2018 to exclude the period of apartheid from the South African economic environment. The specific variables used in the analysis are listed in Table 1, which includes total GDP, agricultural exports, annual income per employee in the sector, agricultural productivity, total employment in agriculture, and agricultural GVA. All variables were converted to natural logarithms to ensure the data are interpreted on the same scale and to minimise the possibility of any variance existing within the dataset.

Table 1: Summary of variables

\begin{tabular}{|l|l|l|l|}
\hline Variable & Role in model & Acronym & $\begin{array}{l}\text { Description and data source (in } \\
\text { brackets) }\end{array}$ \\
\hline $\begin{array}{l}\text { Log of total GDP for } \\
\text { the country }\end{array}$ & $\begin{array}{l}\text { Dependent } \\
\text { variable }\end{array}$ & LGDP & $\begin{array}{l}\text { Total economic output (Quantec, } \\
2019)\end{array}$ \\
\hline $\begin{array}{l}\text { Log of exports in } \\
\text { agricultural sector }\end{array}$ & $\begin{array}{l}\text { Independent } \\
\text { variable }\end{array}$ & LagEXP & $\begin{array}{l}\text { Total exports from the agricultural } \\
\text { sector (Global Insight, 2019) }\end{array}$ \\
\hline $\begin{array}{l}\text { Log of average } \\
\text { income per employee }\end{array}$ & $\begin{array}{l}\text { Independent } \\
\text { variable }\end{array}$ & LagINC & $\begin{array}{l}\text { Average annual income per } \\
\text { employee in the agricultural sector } \\
\text { (Quantec, 2019) }\end{array}$ \\
\hline $\begin{array}{l}\text { Log of productivity in } \\
\text { the agricultural sector }\end{array}$ & $\begin{array}{l}\text { Independent } \\
\text { variable }\end{array}$ & LagPROD & $\begin{array}{l}\text { Productivity in the agricultural } \\
\text { sector (Quantec, 2019) }\end{array}$ \\
\hline $\begin{array}{l}\text { Log of employment in } \\
\text { the agricultural sector }\end{array}$ & $\begin{array}{l}\text { Independent } \\
\text { variable }\end{array}$ & LagEMP & $\begin{array}{l}\text { Total employment in the agricultural } \\
\text { sector (Global Insight, 2019) }\end{array}$ \\
\hline $\begin{array}{l}\text { Log of GVA in the } \\
\text { agricultural sector }\end{array}$ & $\begin{array}{l}\text { Independent } \\
\text { variable }\end{array}$ & LagGVA & $\begin{array}{l}\text { Total GVA produced in the } \\
\text { agricultural sector (Global Insight, } \\
\text { 2019) }\end{array}$ \\
\hline
\end{tabular}

The following ARDL model was estimated:

$$
\begin{aligned}
& L G D P_{t}=a_{0}+\alpha_{1} L G D P_{t-1}+\alpha_{2} \operatorname{LagEXP}_{t-1}+\alpha_{3} \operatorname{LagINC}_{t-1}+\alpha_{4} \operatorname{LagPROD}_{t-1}+ \\
& \alpha_{5} L E M P_{t-1}+\alpha_{6} \text { LagGVA }_{t-1}
\end{aligned}
$$

Where $L G D P_{t}$ represents the change in natural logarithm value of total GDP at time t; $\operatorname{LagEXP_{t}}$ denotes a change in the natural logarithm value of total agricultural exports at time $t ; \operatorname{LagINC}_{t}$ denotes a change in the natural logarithm value of income from agricultural per household, $\operatorname{LagPROD}_{t}$ is the logarithm value of the productivity index of agriculture, $\operatorname{LagEMP} P_{t}$ is the logarithm of total employment in the agricultural sector at time t; and $\operatorname{LagGVA}_{t}$ denotes a change in the natural logarithm value of total agricultural gross value added production in agriculture at time $\mathrm{t}$. The $a_{0}$ denotes the intercept, and $\mathrm{n}$ represents the optimum number of lags. The parameters $\alpha_{i}, \mathrm{i}=1,2,3,4,5$ indicate the long-run multipliers. Equation (1) was estimated for all five variables, indicating that five distinct ARDL models were estimated. Therefore, equation (1) provides the following hypotheses relating to co-integration: 
$>$ Null hypothesis for co-integration $\left(H_{0}: \alpha_{1}=\alpha_{2}=\alpha_{3}=\alpha_{4}=\alpha_{5}=0\right)$

$>$ Alternative hypothesis for co-integration $\left(H_{a}: \alpha_{1} \neq \alpha_{2} \neq \alpha_{3} \neq \alpha_{4} \neq \alpha_{5} \neq 0\right)$

The econometric process included unit root tests for all variables, Bounds test for cointegration, error correction model for short-run relations testing, causality analysis and model stability testing. For the unit root testing, the order of integration for the different variables, the augmented Dickey Fuller (ADF) test (1979) was employed as a test for stationarity. Thereafter, an autoregressive distributed lag model (ARDL), which was developed and subsequently revised by Pesaran et al. (2001), was applied to establish the long-run relationships via the Bounds test, and short-run relationships via an error correction model (ECM) between the variables included in the study. This is because this specific model contains variables with mixed co-integration values at $\mathrm{I}(0)$ and $\mathrm{I}(1)$. One of the main benefits of the ARDL technique is that it is applicable, regardless of the fact that the regressors are entirely $\mathrm{I}(0), \mathrm{I}(1)$ or mutually cointegrated and is also effective when smaller number of observations are included in the model (Narayan \& Smyth, 2005; Naiya \& Manap, 2013). A causality test was employed to analyse the causality of the variables and the direction of relationship (Verter \& Bečvářová, 2016:694). The Granger causality technique was designed with the intention of identifying which variables influence or cause each other to move. The causal relationships among explanatory variables were uncovered using pairwise Grangercausality tests (Verter \& Bečvářová, 2016).

\section{EMPIRICAL RESULTS AND DISCUSSION}

The results section starts with a descriptive analysis of important economic variables related to the agricultural sector as indicated in Table 2. The employment to output (GDP) in agriculture has declined significantly in SA since 1996 to 2018 with an average overall decline of $0.91 \%$ per annum. The sector has over time been mechanised to improve productivity and due to strict labour regulations resulted in an overall loss in employment. Due to ongoing increases in exports in the sector, the export-to-output ratio has increased since 1996 by 3.8\% per annum. Exports have been increasing due to improved productivity and growing global demand. GDP or output in agriculture has also substantially increased due to the same reasons as listed above. GDP has increase on average by $2.4 \%$ per annum. SA is experiencing an investment strike and this is also affecting the agricultural sector with diminishing investment to output since 1996. This is interesting as the sector has experienced significant mechanisation over the last two decades, which requires capital investment. Interestingly, the labour cost per unit in the sector has declined even though a minimum wage policy was introduced. Overall, when looking at the agricultural sector, its contribution towards employment and GVA has declined since 1996 and has reached a low point in 2018 for employment and GVA of $6.4 \%$ and $2.4 \%$, respectively.

Table 2:

\begin{tabular}{|l|r|r|r|r|}
\hline Indicator & \multicolumn{1}{|c|}{$\mathbf{1 9 9 6}$} & \multicolumn{1}{|c|}{$\mathbf{2 0 0 6}$} & \multicolumn{1}{|c|}{$\mathbf{2 0 1 6}$} & $\mathbf{2 0 1 8}$ \\
\hline Employment to output ratio in agriculture & 15.13 & 13.33 & 7.01 & 6.52 \\
\hline Export to output ratio in agriculture & 13.4 & 18.8 & 17.2 & 24.4 \\
\hline GDP in agriculture (R billion at constant prices) & 51.4 & 57.5 & 69.1 & 79.1 \\
\hline Investment to output ratio in agriculture & 0.19 & 0.14 & 0.11 & 0.10 \\
\hline Unit labour cost in agriculture (R at constant prices) & 119.8 & 111.7 & 78.1 & 89.5 \\
\hline \% Contribution of agriculture to total employment & 11.2 & 10.2 & 6.4 & 6.4 \\
\hline \% Contribution of agriculture to total GVA & 4.2 & 2.6 & 2.5 & 2.4 \\
\hline
\end{tabular}

Sources: Quantec, 2019; Global Insight, 2019 
Figure 1 depicts the trends of the variables included in the study. GDP on a national scale is showing a steady increase from 1996 to 2018 with the financial crises clearly visible in 2008/2009. The graph also shows a slowdown from 2016 to 2018. Exports in the agricultural sector were low from 1996 to 2006 and even negative in 2008/2009, but since then have shown rapid increases up to 2018. Income and productivity in the agricultural sector show similar trends in the graphs. Both were limited from 1996 to 2006 with rapid growth from 2007 to 2012, but negative trends from 2015 to 2018. Employment in the sector has been decreasing over the period with a peak in employment in 2007 and a low point in 2011, while GVA has been steadily increasing up to 2016, but with negative trends in 2018 .

Figure 1: Trends analysis of all variables 
GDP at constant prices (R million)(Global Insight)

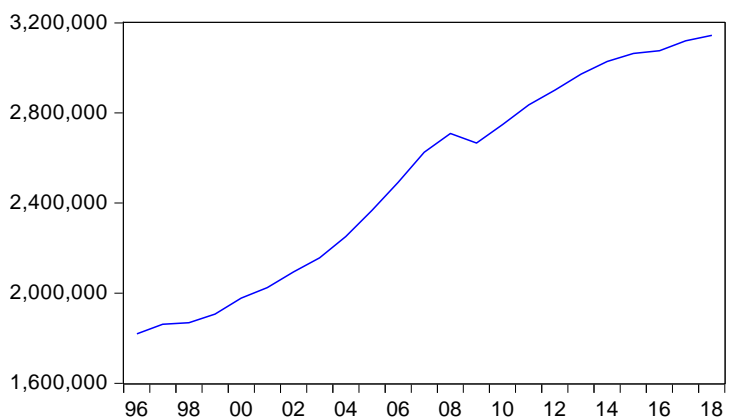

Agric income per employee in Rand constant prices (Quantec)

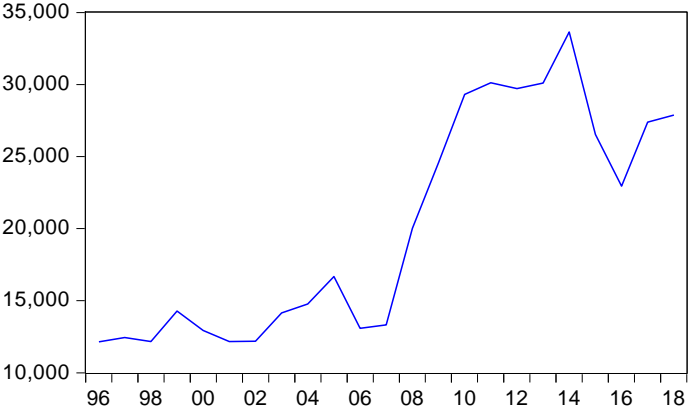

Agric employment (Quantec)

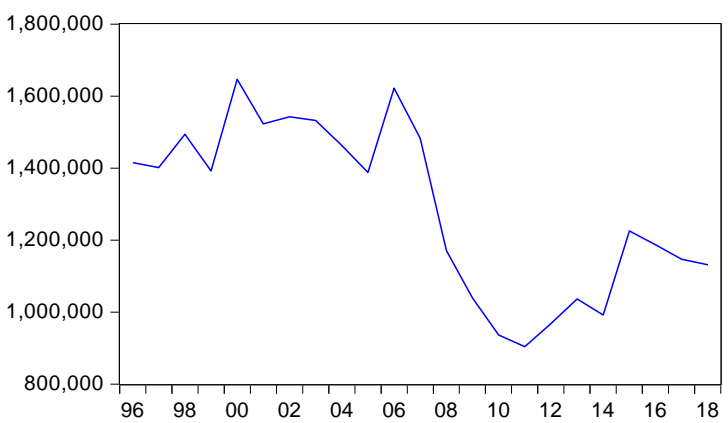

Agric exports constant prices (Rand million) (Global Insight)

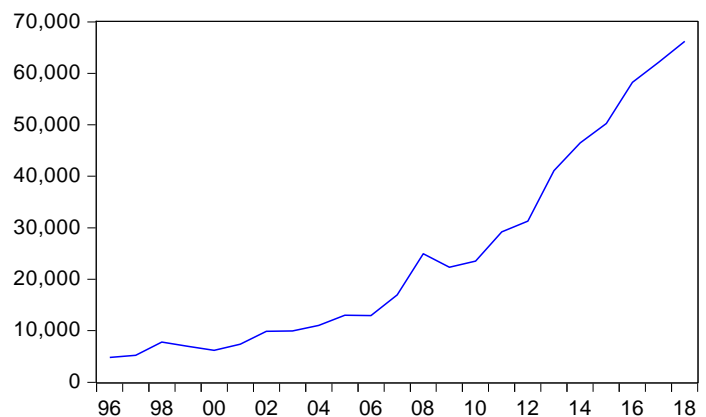

Agric productivity index (Quantec)

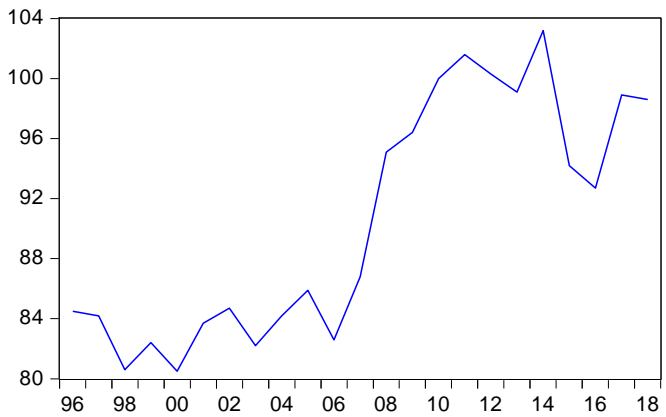

Agric GVA (R millions)(Quantec)

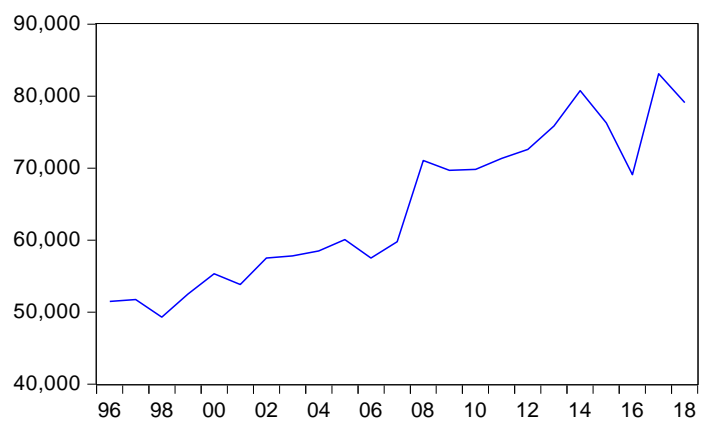

Table 3 indicates the results of the unit root tests, which indicate the level of stationarity of the variables (Yifru, 2015). The results of the test are that all variables are stationary at I(1) or $1^{\text {st }}$ difference. The ADF unit root test is crucial in the selection of the model. The ARDL cointegration model could be used when variables are mixed or even if all variable have the same level of stationarity. The ARDL model was selected due to the relatively small dataset used in this study, although the unit root test results indicate that all variables are stationary at $1^{\text {st }}$ difference or I(1). Consequently, a long-run relationship between the variables ought to be assessed.

Table 3: ADF UNIT ROOT TESTS ( $p$-values)

\begin{tabular}{|l|l|l|c|}
\hline Variable & ADF level & ADF $1^{\text {st }}$ difference & Integration order result \\
\hline LGDP & 0.5502 & $0.0489^{*}$ & $\mathrm{I}(1)$ \\
\hline LagEXP & 0.9932 & $0.0003^{*}$ & $\mathrm{I}(1)$ \\
\hline LagINC & 0.7528 & $0.0077^{*}$ & $\mathrm{I}(1)$ \\
\hline LagPROD & 0.7537 & $0.00010^{*}$ & $\mathrm{I}(\mathrm{I})$ \\
\hline LagEMP & 0.6469 & $0.0025^{*}$ & $\mathrm{I}(\mathrm{I})$ \\
\hline LagGVA & 0.7440 & $0.0001^{*}$ & $\mathrm{I}(1)$ \\
\hline
\end{tabular}

Note: *indicates significance at $5 \%$ level 
the next step in the process was to determine the optimal number of lags to be utilised in the study, by using the Akaike information criteria (AIC) to select the best model. The maximum number of lags proposed by all employed lag selection criteria was one lag. The best model that was selected via the selection model is: $(1,1,0,0,0,1)$. Succeeding the selection of the best ARDL model for each variable, the next step was to estimate the ARDL Bounds test to determine the possibility of a long-run relationship between the variables. Table 4 reports the results of the Bounds test. For this test, the values of the F-statistic need to be higher than the lower and upper bound values. The null hypothesis of this test is that there is no long-run relationship between the different variables. The result of the test is that a long-run relationship exists between the variables.

Table 4: ARDL Bounds test

\begin{tabular}{|l|l|l|}
\hline Test statistic & Value & K \\
\hline F-statistic & 7.276 & 5 \\
\hline Critical value bounds & \multicolumn{2}{|l|}{} \\
\hline Significance & $\mathbf{I}(\mathbf{0})$ Lower bound & I(1) Upper bound \\
\hline $10 \%$ & 1.81 & 2.93 \\
\hline $5 \%$ & 2.14 & 3.34 \\
\hline $2.5 \%$ & 2.44 & 3.71 \\
\hline $1 \%$ & 2.82 & 4.21 \\
\hline
\end{tabular}

From the ARDL estimation, the following long-run equation has been formulated:

$L G D P=25.0927+0.2148^{*} \operatorname{Lag} E X P+0.0952^{*} \operatorname{Lag} I N C+1.2493^{*} \operatorname{Lag} P R O D+0.9897^{*} \operatorname{Lag} E M P$ $+1.0887^{*}$ LagGVA

Equation (3) indicates the coefficients of the long-run relationship between the variables included in the model. Moreover, all of the independent variables have a positive impact on the dependent variable, namely economic growth. The independent variables with the highest coefficient in relation to economic growth are productivity in the agriculture sector with a coefficient of 1.25 , meaning that a $1 \%$ increase in productivity could lead to an $1.25 \%$ increase in economic growth. Thirtle et al. (2003) and Gollin (2010) found similar results with increased productivity in the sector leading to higher economic growth. In addition, the independent variables of GVA in agriculture, employment in agriculture, export in agriculture and income per employee in agriculture have the following coefficients in relation the economic growth of $1.1 \%, 0.9 \%, 0.2 \%$ and $0.1 \%$, respectively. Edeme et al. (2016) stated that the relationship between GDP and agricultural exports can be positive or negative in some countries. Mahmood and Munir (2017) revealed that agricultural exports undergo a positive yet insignificant correlation with economic growth likely due to the sector's inability to participate in the global market, while Sunde (2017) and ljirshar (2015) found that agricultural exports are major drivers of economic growth in the long run.

The ECM and short-run analyses are presented in Table 5. The presence of co-integration necessitated the estimation of the ECM in order to identify the speed of adjustment for longrun equilibrium. The results from the table firstly confirm the long-run relationship via the cointegration equation, which has a negative coefficient and a significant $p$-value as required. This means the model as a whole reverts to equilibrium in both the long- and short run. The table also indicates positive short-run relationships between economic growth and exports in agriculture, income from agriculture and employment in agriculture. 
Table 5: Short-run analysis: ECM

\begin{tabular}{|l|l|l|l|l|l|}
\hline Variable & & Coefficient & Std. error & t-Statistic & Prob. \\
\hline D(LagEXP) & & 0.4585 & 0.1332 & 2.8723 & $0.0297^{\star}$ \\
\hline D(LagINC) & & 0.1717 & 0.0737 & 2.3285 & $0.0367^{\star}$ \\
\hline D(LagPROD) & & 0.4297 & 0.3839 & 1.1193 & 0.2823 \\
\hline D(LagEMPLOY) & & 0.3404 & 0.1556 & 2.1868 & $0.0476^{\star}$ \\
\hline D(LagGVA) & & 0.2096 & 0.1746 & 1.1746 & 0.2516 \\
\hline CointEq(-1) & & $\mathbf{- 0 . 2 8 6 8}$ & $\mathbf{0 . 0 9 6 6}$ & $\mathbf{- 2 . 9 6 9 0}$ & $\mathbf{0 . 0 1 0 9}^{\star}$ \\
\hline
\end{tabular}

$\left(^{*}\right)$ denotes the rejection of the null hypothesis at the $1 \%$ level of significance

The Granger causality results are listed in Table 6 . The causality tests provided additional short-run results. A number of interesting causal relationships exist between the variables, which indicates the strong inter-relationships between the variables as selected. Firstly, a focus on the dependent variable, LGDP. LGDP causes changes in exports in agriculture (LagEXP), and also causes changes in income from agriculture (LagINC), and LGDP also causes all of the other variable to move. Faridi (2012) found similar causality results with a bidirectional causality between economic growth and agricultural exports. Which independent variables causes LGDP to move? Exports, productivity and GVA cause changes in LGDP. Exports in agriculture are an important causality variable and cause changes in income, productivity as well as GVA. Tiffin and Irz (2006) also found that GVA in agriculture causes changes in economic growth. Lastly, productivity in agriculture causes changes in income per employee.

Table 6: Granger causality test

\begin{tabular}{|c|c|c|}
\hline Null hypothesis & Prob. & Outcome \\
\hline LagEXP does not Granger cause LGDP & $0.0323^{*}$ & \multirow[t]{2}{*}{ Bi-directional causality } \\
\hline LGDP does not Granger cause LagEXP & $0.0058^{*}$ & \\
\hline LagINC does not Granger cause LGDP & 0.3500 & \multirow[t]{2}{*}{ Uni-directional causality } \\
\hline LGDP does not Granger cause LagINC & $0.0437^{*}$ & \\
\hline LagPROD does not Granger cause LGDP & $0.0882^{\star \star}$ & \multirow[t]{2}{*}{ Bi-directional causality } \\
\hline LGDP does not Granger cause LagPROD & $0.0174^{*}$ & \\
\hline LagEMPLOY does not Granger cause LGDP & 0.2821 & \multirow[t]{2}{*}{ Uni-directional causality } \\
\hline LGDP does not Granger cause LagEMPLOY & $0.0964^{\star \star}$ & \\
\hline LagGVA does not Granger cause LGDP & $0.0450^{*}$ & \multirow[t]{2}{*}{ Bi-directional causality } \\
\hline LGDP does not Granger cause LagGVA & $0.0004^{*}$ & \\
\hline LagINC does not Granger cause LagEXP & 0.8749 & \multirow[t]{2}{*}{ Uni-directional causality } \\
\hline LagEXP does not Granger cause LagINC & $0.0614^{\star \star}$ & \\
\hline LagPROD does not Granger cause LagEXP & 0.7195 & \multirow[t]{2}{*}{ Uni-directional causality } \\
\hline LagEXP does not Granger cause LagPROD & $0.0872^{\star *}$ & \\
\hline LagGVA does not Granger cause LagEXP & 0.7982 & \multirow[t]{2}{*}{ Uni-directional causality } \\
\hline LagEXP does not Granger cause LagGVA & $0.0010^{*}$ & \\
\hline LagPROD does not Granger cause LagINC & $0.0442^{*}$ & \multirow[t]{2}{*}{ Uni-directional causality } \\
\hline LagINC does not Granger cause LagPROD & 0.9956 & \\
\hline
\end{tabular}

$\left(^{*}\right)$ indicates the rejection of the null hypothesis at $5 \%$ level of significance

$\left.{ }^{* *}\right)$ indicates the rejection of the null hypothesis at $10 \%$ level of significance

Diagnostic and stability tests are designed to authenticate the accuracy of the results the model produces. The tests consist of the normality test, serial correlation, the Breusch-Pagan- 
Godfrey heteroscedasticity test, which was intended for the purpose of deciphering whether variables are homoscedastic or heteroscedastic, as listed in Table 7. Finally, the CUSUM test was developed in order to ascertain the stability of a model. The Jarque-Bera normality test showcases the normal distribution of the explanatory variables; it can be concluded that the model is stable.

Table 7: Diagnostic and stability tests

\begin{tabular}{|l|l|l|}
\hline Test & Prob. & Result \\
\hline Normality test & 0.2211 & Normal distribution \\
\hline Heteroskedasticity test: Breusch-Pagan-Godfrey & 0.9086 & No heteroskedasticity \\
\hline Serial correlation LM test: Breusch-Godfrey & 0.8443 & No serial correlation \\
\hline CUSUM test for model stability & $\mathrm{Na}$ & Model is stabile \\
\hline
\end{tabular}

\section{CONCLUSIONS AND RECOMMENDATIONS}

Most economic analysists agree that the agriculture sector in South Africa is of critical importance for growth of the economy. To this degree, systems and strategies ought to be put in place in order to propel this sector for the industry to operate at its optimal level by means of, for example, policy certainty. The South African economy is currently undergoing low and often stagnant growth, coupled with undesirable levels of unemployment, especially among the youth, alongside high levels of inequality and poverty. The promotion of the agricultural sector could potentially act as a crucial instrument for augmenting inclusive economic growth.

The main findings from the study are that a long-run cointegration relation exists between economic growth and factors in agriculture such as exports, income, productivity, employment and GVA. While, in the short run, only exports, income and employment in agriculture had an impact on economic growth. Granger causality tests indicated that, in the short run, bidirectional relationships exist between economic growth and exports, productivity and GVA. Future studies could include additional variables and testing of other relationships related to the agricultural sector as well as comparative studies between other developing countries. The study is important within the current context in South Africa where land reform processes are imminent and it could change the sector and affect output and food security. Policy recommendations in support of the sector, from the findings included in the study, are that: (1) the sector is critical for economic growth and the creation of employment; (2) productivity advances are important to compete on a global scale, especially for export growth; (3) agriculture is a key economic driver and can play a role in poverty alleviation; (4) the sector is critical for ensuring food security; and (5) improved policy is needed via more research, funding, finance and export incentives.

\section{References}

Awokuse, T.O. \& Xie, R. 2015. Does agriculture really matter for economic growth in developing countries?. Canadian Journal of Agricultural Economics, 63(1), 77-99.

Bakari, S. \& Mabrouki, M. 2017. The Effect of Agricultural Exports on Economic Growth in SouthEastern Europe: An Empirical Investigation using Panel Data. Munich Personal RePEc $\begin{array}{lll}\text { Archive, } & \text { Paper } & \text { No. }\end{array}$ https://mpra.ub.unimuenchen.de/83810/1/MPRA_paper_83810.pdf Date of access: 15 October 2018.

Byerlee, D., De Janvry, A. \& Sadoulet, E. 2009. Agriculture for development: Toward a new paradigm. Annual Review of Resources and Economics, 1(1), 15-31. 
Cervantes-Godoy, D., \& Dewbre, J. 2010. Economic importance of agriculture for poverty reduction.

Cortright, J.C., 2001. New Growth Theory, Technology and Learning: A Practitioner's Guide. Reviews of Economic Development Literature and Practice: No. 4. Portland: EDA

De Janvry, A., \& Sadoulet, E. 2009. Agricultural growth and poverty reduction: Additional evidence. The World Bank Research Observer, 25(1), 1-20.

Delgado, C.L. \& Mellor, J.W. 1984. A Structural View of Policy Issues in African Agricultural Development. American Journal of Agricultural Economics, 66(5): 665-670.

Dethier, J.J. \& Effenberger, A. 2012. Agriculture and development: A brief review of the literature. Economic Systems, 380(1): 1-31.

Dercon, S. \& Gollin, D. 2014. Agriculture in African Development: A Review of Theories and Strategies. Centre for the Study of African Economies, CSAE Working Paper WPS/201422. Oxford: CSAE.

Diao, X., Hazell, P. \& Thurlow, J. 2010. The role of agriculture in African development. World development, 38(10), 1375-1383.

Echevarria, C. 1997. Changes in Sectoral Composition Associated with Economic Growth. International Economic Review, 38 (2): 431-52.

Eddine Chebbi, H. 2010. Agriculture and economic growth in Tunisia. China Agricultural Economic Review, 2(1), 63-78.

Edeme, R.K., Ifelunini, I.A. \& Nkalu, N.A. 2016. A Comparative Analysis of the Impact of Agricultural Exports on Economic Growth of ECOWAS Countries. Acta Oeconomica Pragensia, 24(5): 31-46.

Faridi, M.Z. 2012. Contribution of agricultural exports to economic growth in Pakistan. Pakistan Journal of Commerce and Social Sciences, 6(1), 133-146.

Foster, A.D., \& Rosenzweig, M.R. 2004. Agricultural productivity growth, rural economic diversity, and economic reforms: India, 1970-2000. Economic Development and Cultural Change, 52(3), 509-542.

Fosu, A. K. 1990. Exports and economic growth: The African case. World Development, 18(6): 831-835.

Global Insight Regional Explorer. 2019. Regional data. Pretoria, Global Insight.

Gollin, D. 2010. Agricultural productivity and economic growth. Handbook of Agricultural Economics, 4, 3825-3866.

Gollin, D., Parente, S.L. \& Rogerson, R. 2002. The role of agriculture in development. American Economic Review, 92(2): 160-64.

Hesse, H. 2009. Export diversification and economic growth. Breaking into new markets: emerging lessons for export diversification, 55-80.

ljirshar, V.U. 2015. The empirical analysis of agricultural exports and economic growth in Nigeria. Journal of Development and Agricultural Economics, 7(3): 113-122.

Industrial Development Corporation (IDC). 2018. Economic Trends: key trends in the South African economy. Sandton: IDC Department of Research and Information.

Irz, X., Lin, L., Thirtle, C., \& Wiggins, S. 2001. Agricultural productivity growth and poverty alleviation. Development Policy Review, 19(4), 449-466.

Izuchukwu, O. (2011). Analysis of the contribution of agricultural sector on the Nigerian economic development. World Review of Business Research, 1(1), 191-200. 
Johnston, B.F. \& Mellor, J.W. 1961. The Role of Agriculture in Economic Development. The American Economic Review, 51(4): 566-593.

Lewis, J.D. 2002. Promoting growth and employment in South Africa. South African Journal of Economics, 70(4), 338-358.

Mahmood, K. \& Munir, S. 2018. Agricultural exports and economic growth in Pakistan: an econometric reassessment. Quality \& Quantity, 52(4): 1561-1574.

Malakwane, C.T. 2012. Economic and social effects of unemployment in South Africa: prospects for the future. Tshwane University of Technology. (Thesis - Masters).

Manaka, M. 2018. Agriculture's GDP contribution highlighted to the extended executive management. Limpopo Department of Agriculture and Rural Development, 5 April. http://www.Ida.gov.za/News/Latest\%20News\%20and\%20Events/Pages/Agriculture\%E2\%8 0\%99s-GDP-contribution-highlighted-to-the-Extended-Executive-Management.aspx Date of access: 30 May 2018.

Marsh, S.P. \& Pannell, D. 2000. Agricultural extension policy in Australia: the good, the bad and the misguided. Australian Journal of Agricultural and Resource Economics, 44(4), 605-627.

Marin. D. 1992. Is the Export-Led Growth Hypothesis Valid for Industrialized Countries? The Review of Economics and Statistics, 74(4): 678-688.

Medina-Smith, E.J. 2001. Is the export-led growth hypothesis valid for developing countries? A case study of Costa Rica. Policy Issues in International Trade and Commodities, study series No.7. Geneva: UNCTAD.

Mehrara, M. \& Baghbanpour, J. 2016. The Contribution of Industry and Agriculture Exports to Economic Growth: The Case of Developing Countries. World Scientific News, 46(9): 100111.

Meyer, D.F. 2014. Job creation, a mission impossible? The South African case. Mediterranean Journal of Social Sciences, 5(16): 65-77.

Mohr, P. \& associates. 2015. Economics for South African students. $5^{\text {th }}$ edition. Pretoria: Van Schaik Publishers.

Naiya, I.I. \& Manap, T.A. 2013. Structural Transformation, Poverty and Inequality in Nigeria: An ARDL Bound Testing Technique. International Journal of Economics and Finance, 5(4): 141-152.

Narayan, P. \& Smyth, R. 2005. Trade liberalization and economic growth in Fiji. An empirical assessment using the ARDL approach. Journal of the Asia Pacific Economy, 10(1): 96115.

Nwachukwu, I.N. \& Ezeh, C.I. 2007. Impact of selected rural development programmes on poverty alleviation in Ikwuano LGA, Abia State, Nigeria. African Journal of Food Agriculture Nutrition and Development, 7(5): 1-17.

Olajide, O.T., Akinlabi, B.H. \& Tijani, A.A. 2012. Agriculture Resource and Economic Growth in Nigeria. European Scientific Journal, 8(22): 103-115.

Pauw, K., \& Thurlow, J. 2011. Agricultural growth, poverty, and nutrition in Tanzania. Food Policy, 36(6), 795-804.

Pesaran, H.M., Shin, Y. \& Smith, R. 1996. Testing the existence of a long-run relationship. DAE Working Paper Series, No. 9622. Department of Applied Economics, Cambridge: Cambridge University

Pesaran, H.M., Shin, Y. \& Smith, R. 2001. Bound Testing Approaches to the Analysis of Level Relationship. Journal of Applied Econometrics, 16(1): 289-326. 
Pfunzo, R. 2017. Agricultural contribution to economic growth and development in rural Limpopo province: A Sam multiplier analysis. Stellenbosch: Stellenbosch University. (Thesis Masters).

Po-Chi, C.H.E.N., Ming-Miin, Y.U., Chang, C.C., \& Shih-Hsun, H.S.U. 2008. Total factor productivity growth in China's agricultural sector. China Economic Review, 19(4), 580-593.

Quantec Easy Data. 2019. Data set. Johannesburg, Quantec.

Raza, S.A., Ali, Y., \& Mehboob, F. 2012. Role of agriculture in economic growth of Pakistan.

Romer, P. 1994. New goods, old theory, and the welfare costs of trade restrictions. Journal of Development Economics, 43(1): 5-38.

Sertoglu, K., Ugural, S., \& Bekun, F.V. 2017. The contribution of agricultural sector on economic growth of Nigeria. International Journal of Economics and Financial Issues, 7(1), 547-552.

South African Revenue Services (SARS). 2018. Trade Balance Trend (Exports vs Imports since 2010). http://tools.sars.gov.za/Tradestatsportal/Chart.aspx. Date of access: 06 Mar 18.

Solow, R.M. 1956. A contribution to the theory of economic growth. The Quarterly Journal of Economics, 70(1): 65-94.

South Africa. Department of Agriculture, Forestry \& Fisheries. 2017. Economic review of the South African agriculture 2016/17. http://www.daff.gov.za/Daffweb3/Portals.pdf. Date of access: 30 May 2019.

South Africa. Department of Agriculture, Forestry and Fisheries (DAFF). 2018. Annual Performance Plan for the 2018/19 fiscal year. Pretoria: Department of Trade and Industry.

Statistics South Africa (Stats SA). 2017b. Poverty Trends in South Africa. http://www.statssa.gov.za/publications/Report-03-10-06/Report-03-10-062015.pdf. Date of access: 06 March 2019.

Statistics South Africa (Stats SA). 2018a. Quarterly Labour Force Survey, Quarter 2, 2018. Pretoria: Statistics South Africa.

Statistics South Africa (Stats SA). 2018b. Mid-year population estimates 2018. Pretoria: Statistics South Africa.

Sunde, T. 2017. Foreign direct investment, exports and economic growth: ADRL and causality analysis for South Africa. Research in International Business and Finance, 41(1): 434-444.

Thaker, H.M.T., Ee, T.S. \& Vaidik, S. 2013. Export-led growth hypothesis: econometric evidence from Malaysia. Journal of International Business and Economy, 14(2): 95-112.

Tiffin, R. \& Irz, X. 2006. Is agriculture the engine of growth? Agricultural Economics, 35(1), 79-89.

The Presidency. 2017. Remarks by President Jacob Zuma during the AFASA Agribusiness Transformation Gala Dinner http://www.thepresidency.gov.za/speeches/remarks-president-jacob-zuma-during-afasaagribusiness-transformation-conference-gala Date of access: 07 March 18

Thirtle, C., Lin, L., \& Piesse, J. 2003. The impact of research-led agricultural productivity growth on poverty reduction in Africa, Asia and Latin America. World Development, 31(12), 19591975.

Turan Katircioglu, S. 2006. Causality between agriculture and economic growth in a small nation under political isolation: A case from North Cyprus. International Journal of Social Economics, 33(4), 331-343.

Udemezue, J.C. \& Osegbue, E.G. 2018. Theories and models of agricultural development. Annals of Reviews and Research, 1(5), 1-4. 
Verter, N. \& Bečvářová, V. 2016. The impact of agricultural exports on economic growth in Nigeria. Acta Universitatis Agriculturae et Silviculturae Mendelianae Brunensis, 64(2): 691700.

White, B. 2012. Agriculture and the generation problem: rural youth, employment and the future of farming. IDS Bulletin, 43(6), 9-19.

World Bank. 2007. World development report 2008: Agriculture for Development. Washington, DC: The World Bank.

World Bank. 2018. Overcoming Poverty and Inequality in South Africa: An assessment of Drivers, Constraints and Opportunities. Washington, DC: World Bank Group.

Yifru, T. 2015. Impact of Agricultural Exports on Economic Growth in Ethiopia: The Case of Coffee, Oilseed and Pulses. Nairobi: Egerton University. (Thesis - Masters). 